\title{
KAJIAN pH DAN KADAR AIR DALAM SNI SABUN MANDI PADAT DI JABEDEBOG
}

\author{
Study of pH and Moisture Content in SNI of Bar Bath Soap in Jabedebog \\ Ira Setiawati ${ }^{1}$ dan Auliyah Ariani ${ }^{2}$ \\ 1,2Badan Penelitian dan Pengembangan Industri - Kementerian Perindustrian \\ Jl. Balai Kimia No.1, Pekayon, Pasar Rebo, Jakarta Timur, 13069 \\ E-mail: ira.setiawati@gmail.com
}

\begin{abstract}
Abstrak
Produk kimia pembersih seperti sabun mandi padat merupakan produk wajib yang diperlukan setiap orang sejak munculnya penyakit yang disebabkan oleh coronavirus pada akhir Tahun 2019 atau sering disebut COVID-19. Sabun tersebut digunakan untuk membersihkan seluruh anggota tubuh dari kotoran atau mikroba dan mencegah masuknya virus ke dalam tubuh manusia. Oleh karena produk sabun tersebut kontak langsung terhadap kulit manusia, maka perlu diperhatikan mutu pH sabun tersebut. Namun, standar yang ada baik di Indonesia maupun Negara lain belum menyantumkan persyaratan mutu $\mathrm{pH}$ pada produk sabun mandi padat. Selain itu, parameter kadar air juga perlu diperhatikan karena dapat mempengaruhi karakteristik sabun yang disimpan. Tujuan penelitian ini adalah untuk memperoleh dan mengkaji data $\mathrm{pH}$ dan kadar air dari produk sabun mandi padat yang beredar, yang selanjutnya digunakan sebagai rekomendasi perbaikan SNI Sabun mandi padat (SNI 3532:2016). Metode penelitian yang digunakan adalah eksploratif kuantitatif yaitu mengumpulkan produk dan melakukan pengecekan mutu produk sabun mandi padat yang beredar di wilayah Jakarta, Bekasi, Depok, dan Bogor. Hasil evaluasi mutu dari sabun mandi padat tersebut menunjukkan bahwa nilai $\mathrm{pH}$ sabun mandi padat berada pada rentang 9,99 - 10,47 dan kadar air sabun mandi padat pada rentang 5,42\% - 28,41\%. Data ini dapat digunakan sebagai acuan dalam perbaikan SNI yang sudah ada, sehingga diharapkan perbaikan SNI tersebut dapat meningkatkan daya saing produk sabun mandi padat Indonesia.
\end{abstract}

Kata kunci: pH, kadar air, sabun mandi padat, Standar Nasional Indonesia (SNI).

\begin{abstract}
Abstrak
Chemical cleaning products such as bar bath soap are mandatory products that everyone needs since the emergence of the disease caused by the coronavirus at the end of 2019 or called COVID-19. The soap is used to clean all parts of the body from dirt or microbes and prevent viruses from entering the human body. Because the soap is in direct contact with human skin, it is necessary to pay attention to the $\mathrm{pH}$ quality of the soap. However, existing standards both in Indonesia and other countries do not included $\mathrm{pH}$ quality requirements on bar bath soap. Also, the water content parameter needs to be considered because it can affect the characteristics of the stored soap. The purpose of this study was to obtain and evaluate data on $\mathrm{pH}$ and moisture content of bar bath soap in the markets, which were then used as recommendations for improvement of SNI for bar bath soap (SNI 3532:2016). The research method is quantitative exploratory, by collecting products and checking the quality of bar bath soap in the areas of Jakarta, Bekasi, Depok, and Bogor. The results show that the $\mathrm{pH}$ value is in the range of $9.99-10.47$ and the water content is in the range of $5.42 \%-24.81 \%$. These data can be used as a reference in improving the existing SNIs so that these can increase the competitiveness of Indonesia bar bath soap products.
\end{abstract}

Key words: $\mathrm{pH}$, moisture content, bar bath soap, Indonesian National Standard.

\section{PENDAHULUAN}

Industri kimia pembersih merupakan industri yang memiliki peranan penting dalam kehidupan sehari-hari. Salah satu produk kimia pembersih yang paling banyak digunakan adalah sabun. Hal ini ditunjukkan oleh data dari Kementerian Perdagangan bahwa permintaan sabun di dunia untuk 5 tahun terakhir meningkat 2,29\% per tahun yaitu pada Tahun 2014 - 2018. Pada laporan tersebut juga disebutkan bahwa Indonesia menjadi negara ketiga pengekspor sabun di dunia dan menjadi negara pertama di ASEAN pada Tahun 2018 (Ministry of Trade Republic of Indonesia, 2019).

Perkembangan industri sabun di Indonesia dipengaruhi oleh lokasi Indonesia yang berada di iklim tropis sehingga menyebabkan gaya hidup untuk mandi secara teratur sehingga sabun menjadi kebutuhan utama masyarakat 
Indonesia. Saat ini, perkembangan industri sabun juga dipengaruhi oleh kasus tertentu seperti pandemi COVID-19 atau peristiwa menyebarnya coronavirus sejak akhir tahun 2019. Sejak pandemi COVID-19, World Health Organization (WHO) menyarankan kepada masyarakat untuk lebih sering mencuci tangan dalam tindakan pencegahan penyebaran virus tersebut (Chaudhary et al., 2020; Nakoe, S lalu, \& Mohamad, 2020). Hal ini menyebabkan penggunaan sabun semakin meningkat terutama sabun mandi padat karena produk tersebut lebih murah, lebih mudah digunakan, dan efisien dalam membersihkan kulit dibandingkan dengan sabun mandi cair (Febriani, Syafriana, Afriyando, \& Djuhariah, 2020). Oleh karena produk sabun mandi padat digunakan oleh masyarakat luas, maka produk tersebut harus memiliki standar spesifikasi produk yang sesuai, sehingga dapat memenuhi kebutuhan dan melindungi konsumen. Meskipun produk sabun mandi padat diproduksi sesuai spesifikasi dan perkembangan peraturan yang berlaku, pengawasan kualitas yang standar pada produk yang di jual di pasar terbuka menjadi penting (Idoko, Emmanuel, Salau, \& Obigwa, 2018). Standar produk mencakup persyaratan mutu dari parameterparameter uji yang perlu dipenuhi oleh suatu produk. Dalam penggunaannya, sabun tersebut kontak langsung terhadap kulit manusia. Jika sabun yang digunakan sudah memenuhi standar mutu produk, maka sabun tersebut aman digunakan. Parameter uji yang dapat menunjukkan secara langsung kriteria sabun yang layak digunakan atau tidak adalah $\mathrm{pH}$ dan kadar air.

Sabun mandi padat merupakan produk hasil saponifikasi, dimana proses ini membutuhkan sejumlah alkali agar terjadi reaksi yang sempurna. Jumlah alkali yang digunakan berkaitan erat dengan kadar $\mathrm{pH}$ sabun yang dihasilkan. Setiap produsen sabun pasti memiliki formulasi pembuatan sabun yang berbeda-beda. Jika komposisi bahan baku tidak tepat, maka akan menghasilkan $\mathrm{pH}$ sabun yang berbedabeda. Agar produk sabun yang diproduksi aman digunakan konsumen, maka perlu batasan atau persyaratan mutu $\mathrm{pH}$ tersebut. Permasalahannya adalah persyaratan mutu $\mathrm{pH}$ sabun mandi padat belum dicantumkan baik dalam Standar Nasional Indonesia (SNI 3532:2016) maupun standar Negara lain seperti India (Bureau of Indian Standards, 1997), Afrika Timur (East African Community, 2011), dan Pakistan (Pakistan Standards and Quality Control Authority, 2009). Mengingat pentingnya nilai $\mathrm{pH}$ pada sabun mandi padat, maka perlu dievaluasi nilai $\mathrm{pH}$ pada sabun mandi padat yang beredar di pasaran dan merekomendasikan perbaikan SNI 3532:2016 untuk mencantumkan syarat mutu $\mathrm{pH}$.

Selain $\mathrm{pH}$, mutu sabun juga ditentukan oleh kadar air. Kadar air dapat mempengaruhi karakteristik sabun seperti sifat keras. Sabun mandi padat yang beredar di pasaran memiliki tekstur kekerasan sabun yang beragam. Hal ini dipengaruhi oleh jumlah air yang terkandung dalam sabun berbeda-beda. Sifat keras tersebut dapat mempengaruhi umur simpan produk. Oleh karena itu, perlu adanya batasan persyaratan mutu kadar air yang sesuai. Permasalahan yang ada adalah kadar air dalam SNI 3532:2016 memiliki syarat mutu maksimal $15 \%$ fraksi massa. Nilai tersebut perlu dikaji ulang, apakah produk yang dipasaran sudah sesuai dengan persyaratan mutu tersebut.

Berdasarkan permasalahan yang telah disebutkan, perlu dilakukan kajian terhadap nilai $\mathrm{pH}$ dan kadar air produk sabun mandi padat yang beredar di pasaran agar produk tersebut memiliki daya saing yang tinggi. Selanjutnya, data hasil evaluasi dapat digunakan sebagai acuan rekomendasi perbaikan standar mutu yang ada.

\section{TINJAUAN PUSTAKA}

Sabun mandi padat adalah sediaan pembersih kulit berbentuk padat yang dibuat dari proses saponifikasi atau netralisasi dari lemak, minyak, wax, rosin atau asam dengan basa organik atau anorganik tanpa menimbulkan iritasi pada kulit (Badan Standardisasi Nasional, 2016). Sabun mandi padat digunakan untuk membersihkan tangan, wajah, dan badan. Sabun mandi padat juga dapat melembabkan kulit dan menghambat bakteri penyebab bau, tergantung pada bahan tambahan lainnya dalam proses pembuatannya.

Sifat fisikokimia sabun tergantung pada beberapa faktor yang meliputi tingkat dan kemurnian alkali, jenis minyak yang digunakan dan proses saponifikasi. Fisikokimia tersebut meliputi kadar air, total lemak, pH, alkali bebas, kadar klorida. Sabun yang baik adalah sabun yang memenuhi karakteristik sesuai standar yang berlaku (Habib et al., 2016; Idoko et al., 2018; Vivian, Nathan, Osano, Mesopirr, \& Omwoyo, 2014). Standar Nasional Indonesia (SNI) yang berlaku saat ini adalah SNI Sabun mandi padat 3532:2016 dengan persyaratan mutu seperti pada Tabel 1. 
Tabel 1 Persyaratan mutu sabun mandi padat dalam SNI 3532:2016 (Badan Standardisasi Nasional, 2016).

\begin{tabular}{|c|c|c|c|}
\hline No & Parameter uji & Satuan & $\begin{array}{c}\text { Persyaratan } \\
\text { mutu }\end{array}$ \\
\hline 1 & Kadar air & $\begin{array}{c}\% \text { fraksi } \\
\text { massa }\end{array}$ & maks. 15,0 \\
\hline 2 & Total lemak & $\begin{array}{l}\% \text { fraksi } \\
\text { massa }\end{array}$ & $\min .65,0$ \\
\hline 3 & $\begin{array}{l}\text { Bahan tak larut } \\
\text { dalam etanol }\end{array}$ & $\begin{array}{l}\% \text { fraksi } \\
\text { massa }\end{array}$ & maks. 5,0 \\
\hline 4 & $\begin{array}{l}\text { Alkali bebas } \\
\text { (dihitung sebagai } \\
\mathrm{NaOH} \text { ) }\end{array}$ & $\begin{array}{l}\text { \% fraksi } \\
\text { massa }\end{array}$ & maks. 0,1 \\
\hline 5 & $\begin{array}{l}\text { Asam lemak } \\
\text { bebas (dihitung } \\
\text { sebagai Asam } \\
\text { oleat) }\end{array}$ & $\begin{array}{l}\text { \% fraksi } \\
\text { massa }\end{array}$ & maks. 2,5 \\
\hline 6 & Kadar klorida $\left(\mathrm{Cl}^{-}\right)$ & $\begin{array}{l}\% \text { fraksi } \\
\text { massa }\end{array}$ & maks. 1,0 \\
\hline 7 & $\begin{array}{l}\text { Lemak tidak } \\
\text { tersabunkan }\end{array}$ & $\begin{array}{l}\% \text { fraksi } \\
\text { massa }\end{array}$ & maks. 0,5 \\
\hline
\end{tabular}

\section{$2.1 \quad \mathrm{pH}$ sabun mandi}

Derajat keasaman atau $\mathrm{pH}$ merupakan parameter penting yang digunakan untuk menilai kelayakan sabun dapat digunakan sebagai sabun mandi. Pada umumnya, sabun bersifat basa terhadap larutan air karena sabun merupakan garam dari asam lemah (asam lemak) dan basa. Nilai $\mathrm{pH}$ sabun yang tidak sesuai dapat mempengaruhi $\mathrm{pH}$ kulit. Hal ini disebabkan oleh zat alkali pada sabun dapat menetralkan atau bahkan dapat merusak (jika $\mathrm{pH}$ sabun sangat basa) mantel asam pada kulit yang bertindak sebagai penghalang bakteri dan virus, serta mengakibatkan kulit kering karena kehilangan air sehingga memungkinkan potensi terjadinya iritasi dan alergi. Hal tersebut terjadi ketika sabun yang kontak dengan air akan mengalami hidrolisis, sehingga melepaskan alkali yang terkandung di dalamnya dan meningkatkan $\mathrm{pH}$ kulit menjadi 10 sampai 11 . Diketahui bahwa kulit sehat umumnya memiliki pH 5,4 sampai 5,9 (Habib et al., 2016; Mendes, Shimabukuro, Uber, and Abagge, 2016; Vivian et al., 2014).

Tinggi rendahnya $\mathrm{pH}$ sabun dipengaruhi oleh proses saponifikasi saat pembuatan sabun. Nilai $\mathrm{pH}$ sabun yang tinggi dihasilkan dari reaksi hidrolisis pada proses saponifikasi tersebut. Hal ini dapat diatasi dengan menambahkan lemak atau minyak berlebih. Namun, penambahan lemak atau minyak akan mengurangi kekerasan sabun (Habib et al., 2016; Vivian et al., 2014).

Beberapa penelitian telah melaporkan bahwa sabun pada umumnya memiliki $\mathrm{pH}$ berkisar antara 9,01 sampai 10,00 dan sedikit produk yang memiliki pH sesuai $\mathrm{pH}$ kulit (Tarun, Susan, Suria, Susan, \& Criton, 2014); 69,4\% dari sampel sabun dan produk pembersih yang diteliti memiliki pH basa dengan kisaran 9,3 - 10,7 (Dlova, Naicker, and Naidoo, 2017). Produk sabun dengan berbagai nilai $\mathrm{pH}$ dapat ditemukan di dunia, namun penggunaannya disesuaikan oleh masing-masing konsumen. Oleh karena itu dibutuhkan pandangan yang lebih luas tentang pentingnya $\mathrm{pH}$ pada produk sabun (Arefin, Tamjid-Us-Sakib, Habib, Saha, and Boby, 2020).

\subsection{Kadar air sabun mandi}

Kadar air merupakan parameter yang digunakan dalam menilai umur simpan suatu produk. Kadar air yang tinggi dalam sabun akan menyebabkan reaksi kelebihan air dengan lemak yang tidak disaponifikasi untuk menghasilkan asam lemak bebas dan gliserol dalam proses yang disebut hidrolisis sabun pada penyimpanan (Idoko et al., 2018; Vivian et al., 2014).

Sabun dengan kadar air yang sangat tinggi akan lebih cepat mengalami penyusutan bobot. Jumlah air yang ditambahkan pada sabun juga akan berpengaruh terhadap kelarutan sabun. Semakin banyak air yang ditambahkan dalam sabun maka sabun akan mudah menyusut pada saat digunakan (Mumpuni \& Sasongko, 2017). Sedangkan sabun yang memiliki kadar air yang sedikit akan meningkatkan umur simpan produk sabun tersebut (Habib et al., 2016).

Setiap sabun memiliki kadar air berbeda karena setiap produsen memiliki formulasi pembuatan sabun yang berbeda. Beberapa penelitian melaporkan bahwa 5 contoh sabun mandi dengan merk terkenal di Indonesia memiliki kadar air 9,64\% - 11,80\% (Habib et al., 2016). Sedangkan sabun komersial di Kenya memiliki kadar air terendah $(10,91 \pm 1,27) \%$ dan tertinggi $(22,69 \pm 0,94) \%$ (Vivian et al., 2014).

\section{METODE PENELITIAN}

Metode penelitian yang digunakan merupakan penelitian eksploratif kuantitatif. Penelitian dilakukan pada Juli - September 2020. Produk sabun mandi padat dari semua merk dikumpulkan dari tempat pembelian (minimarket dan supermarket) yang terletak di Kota Jakarta, Kota Bekasi, Kota Depok dan Kota Bogor (Jabedebog), Indonesia. Produk yang dipilih sebagai contoh penelitian adalah produk dengan harga maksimal Rp10.000, yaitu harga yang dapat dijangkau oleh masyarakat umum. Tiga puluh dua (32) jenis sabun mandi padat dianalisis, dibagi menjadi 2 kategori yang terdiri dari 22 sabun mandi padat dan 10 sabun mandi padat antiseptik. Nilai $\mathrm{pH}$ dan kadar air dari semua contoh sabun dianalisa sesuai metode 
standar yang berlaku dan analisa dilakukan di Laboratorium Pengujian Kimia Balai Besar Kimia dan Kemasan (BBKK), Kementerian Perindustrian, Jakarta.

\subsection{Persiapan Contoh Uji}

Contoh sabun mandi padat diparut halus dan disimpan dalam wadah yang bersih, kering, dan tertutup rapat. Contoh diberi identifikasi $S$ untuk sabun mandi padat biasa dan $A$ untuk sabun mandi padat antiseptik.

\subsection{Pengujian $\mathrm{pH}$}

Pengujian $\mathrm{pH}$ dilakukan sesuai ASTM D1172-15. Contoh uji ditimbang 1 gram dan pindahkan ke dalam labu ukur $1000 \mathrm{~mL}$, kemudian ditambahkan air suling bebas $\mathrm{CO}_{2}$ hingga tanda tera. Labu ukur ditutup dan larutan dihomogenkan. Lalu, larutan dituang ke dalam gelas piala dan didiamkan untuk mencapai kesetimbangan pada suhu ruang $(25 \pm 2,0)^{\circ} \mathrm{C}$. Selanjutnya $\mathrm{pH}$ larutan diukur menggunakan $\mathrm{pH}$ meter yang telah dikalibrasi dengan larutan buffer 4, 7 dan 10 (American Society for Testing and Materials International, 2015).

\subsection{Pengujian Kadar Air}

Pengujian kadar air dilakukan menggunakan metode ASTM D460-91. SNI Sabun mandi padat tidak digunakan untuk pengujian kadar air karena terdapat ketidaksesuaian dalam rumus perhitungannya. Contoh uji ditimbang 5 gram ke dalam cawan petri yang telah dikeringkan dalam oven pada suhu $(105 \pm 2,0)^{\circ} \mathrm{C}$ selama 30 menit. Kemudian contoh uji tersebut dipanaskan dalam oven pada suhu $(105 \pm 2,0)^{\circ} \mathrm{C}$ selama 1 jam. Setelah itu, didinginkan dalam desikator dan ditimbang. Pengukuran dilakukan sampai diperoleh bobot tetap (American Society for Testing and Materials International, 2014).

\section{HASIL DAN PEMBAHASAN}

Produk sabun mandi padat yang beredar di Indonesia, khususnya di Kota Jakarta, Kota Bekasi, Kota Depok dan Kota Bogor sangat beragam merk dan jenisnya. Hal ini dapat memberikan banyak pilihan bagi masyarakat umum untuk menentukan produk sabun yang akan digunakan. Oleh karena itu, penerapan standar mutu sabun mandi lokal di Indonesia sangat diperlukan untuk meningkatkan daya saing dengan produk luar.

\subsection{Hasil Pengujian pH}

Nilai pH merupakan parameter yang sangat penting dalam sabun mandi padat karena kelayakan sabun untuk digunakan sebagai sabun mandi dilihat dari nilai $\mathrm{pH}$. Data $\mathrm{pH}$ dari 32 contoh sabun pada penelitian ini dapat dilihat di Tabel 2. Hasil menunjukkan bahwa $\mathrm{pH}$ dari sabun mandi padat berada pada rentang 9,99 10,42 dan $\mathrm{pH}$ dari sabun mandi padat antiseptik berada pada rentang 9,99-10,47. Hasil tersebut sudah memenuhi persyaratan $\mathrm{pH}$ sabun yang aman yaitu 9 - 11 (American Society for Testing and Materials International, 2015).

Pada dasarnya sabun mandi padat untuk jenis true soap yang dibuat dari lemak dan alkali melalui cold process, pasti memiliki $\mathrm{pH}$ antara 9 - 10. Hal ini dikarenakan, sabun mandi yang diproduksi dengan metode cold process tidak akan bisa mencapai $\mathrm{pH}$ normal atau 7. Jika $\mathrm{pH}$ sabun diturunkan hingga 7 , maka sabun akan terpisah kembali menjadi minyak dan air alkali. Sabun mandi yang memiliki $\mathrm{pH} 9-10$ merupakan tempat yang tidak disukai oleh bakteri dan mikroba, jadi tidak perlu ditambahkan zat antibakteri ke sabun tersebut. Sedangkan sabun dengan $\mathrm{pH}$ normal sangat disukai oleh bakteri dan mikroba, sehingga sabun tersebut perlu dilengkapi dengan zat antibakteri.

Besarnya nilai $\mathrm{pH}$ dipengaruhi oleh jumlah alkali yang ada dalam sabun. Semakin banyak jumlah alkali dalam sabun, maka semakin tinggi nilai $\mathrm{pH}$ sabun tersebut. Banyaknya jumlah alkali dalam sabun disebabkan adanya alkali yang tidak bereaksi dengan asam lemak dalam proses saponifikasi (Mumpuni \& Sasongko, 2017). Nilai $\mathrm{pH}$ yang lebih tinggi membuat sabun mudah berbusa karena bersifat basa.

Tabel 2 Hasil analisa $\mathrm{pH}$ sabun mandi padat di pasaran.

\begin{tabular}{cccc}
$\begin{array}{c}\text { Kode } \\
\text { contoh }\end{array}$ & $\begin{array}{c}\mathbf{p H} \\
(\mathbf{0 , 1} \mathbf{1} \mathbf{b} / \mathbf{v})\end{array}$ & $\begin{array}{c}\text { Kode } \\
\text { contoh }\end{array}$ & $\mathbf{p H}(\mathbf{0 , 1} \mathbf{1} \mathbf{b} / \mathbf{v})$ \\
\hline S1 & 10,17 & $\mathrm{~A} 1$ & 10,27 \\
S2 & 10,19 & $\mathrm{~A} 2$ & 10,16 \\
S3 & 10,16 & $\mathrm{~A} 3$ & 10,47 \\
S4 & 10,01 & $\mathrm{~A} 4$ & 10,28 \\
S5 & 10,10 & $\mathrm{~A} 5$ & 9,99 \\
S6 & 10,18 & $\mathrm{~A} 6$ & 10,28 \\
S7 & 10,24 & $\mathrm{~A} 7$ & 10,26 \\
S8 & 10,20 & $\mathrm{~A} 8$ & 10,08 \\
S9 & 10,33 & $\mathrm{~A} 9$ & 10,17 \\
S10 & 10,27 & $\mathrm{~A} 10$ & 10,24 \\
S11 & 10,24 & & \\
S12 & 10,22 & & \\
S13 & 10,17 & & \\
S14 & 9,99 & & \\
S15 & 10,26 & & \\
S16 & 10,28 & & \\
S17 & 10,13 & & \\
S18 & 10,42 & & \\
S19 & 10,14 & & \\
S20 & 10,31 & & \\
S21 & 10,23 & & \\
S22 & 10,32 & & \\
\hline
\end{tabular}


Pengecekan $\mathrm{pH}$ sabun diperlukan tidak hanya untuk tujuan meningkatkan kualitas sabun, tetapi juga untuk mengatur tingkat $\mathrm{pH}$ sehingga tidak merusak kulit (Warra, 2013). Produk sabun mandi yang memiliki $\mathrm{pH}$ sangat rendah dapat juga digunakan tetapi untuk kepentingan konsumen khusus dan sesuai persyaratan medis.

Secara umum, menggunakan sabun yang sedikit asam atau sedikit basa dalam waktu singkat (seperti sabun untuk mencuci tangan atau mandi) tidak akan merusak mantel asam. Kulit yang sehat dapat menyeimbangkan kembali mantel asal dalam waktu yang sangat singkat (hanya dalam 15 menit hingga 90 menit). Hal yang dapat merusak kulit adalah ketika kulit terpapar dalam jangka waktu yang panjang oleh bahan yang sangat asam (seperti asam sulfat) atau sangat basa (seperti natrium hidroksida) atau seperti mengaplikasikan produk $\mathrm{pH}$ tinggi ke kulit dan membiarkannya selama berjam-jam tanpa pencucian (Takagi et al., 2014).

Berdasarkan hasil uji, kedua jenis sabun tersebut menghasilkan rentang $\mathrm{pH}$ yang sama dengan nilai $\mathrm{pH}$ sedikit basa (sekitar $9-10$ ), sehingga produk sabun mandi padat yang beredar di pasaran masih aman digunakan oleh masyarakat. Data tersebut selanjutnya dapat dijadikan acuan dalam rekomendasi usulan penambahan syarat mutu $\mathrm{pH}$ dan nilainya ke dalam SNI Sabun mandi padat dan SNI Sabun mandi padat antiseptik yang merupakan perbaikan SNI sabun mandi berkarbol. Dengan adanya perbaikan $\mathrm{SNI}$, diharapkan produsen sabun dapat mengikuti perkembangan produk yang ada sehingga memudahkan industri dalam pengklasifikasian produk yang akan dipasarkan.

\subsection{Hasil Pengujian Kadar Air}

Hasil pengujian kadar air pada Tabel 3 menunjukkan bahwa contoh sabun di pasaran memiliki kadar air yang bervariasi. Kadar air pada sabun mandi padat berada pada rentang $6,04 \%-28,41 \%$, sedangkan sabun mandi padat antiseptik berada pada rentang $5,42 \%-12,40 \%$.

Kadar air dalam sabun mandi padat menunjukkan jumlah air yang ada dalam sabun tersebut. Sabun dengan kadar air yang tinggi akan lebih cepat mengalami penyusutan pada saat digunakan. Sedangkan, sabun yang mengandung sedikit air dapat meningkatkan masa simpannya. Namun, lamanya penyimpanan sabun dapat mempengaruhi kekerasan sabun karena kandungan air di dalam sabun semakin lama semakin menguap (Febriani et al., 2020). Oleh karena itu, kadar air produk sabun mandi padat sangat menentukan karakteristik sabun yang disimpan selama penjualan dan saat digunakan oleh masyarakat. Jika kadar air terlalu kecil, sabun menjadi terlalu keras ketika sampai di konsumen dan menjadi kurang nyaman saat digunakan. Hal ini dikarenakan, mulai dari produsen sampai sabun tersebut digunakan oleh konsumen, membutuhkan waktu yang tidak sebentar dan pasti terjadi penguapan kandungan air di dalam sabun tersebut.

Tabel 3 Hasil analisa kadar air sabun mandi padat di pasaran.

\begin{tabular}{cccc}
$\begin{array}{c}\text { Kode } \\
\text { contoh }\end{array}$ & $\begin{array}{c}\text { Kadar air } \\
(\%)\end{array}$ & $\begin{array}{c}\text { Kode } \\
\text { contoh }\end{array}$ & Kadar air (\%) \\
\hline S1 & 8,91 & $\mathrm{~A} 1$ & 5,42 \\
S2 & 7,97 & $\mathrm{~A} 2$ & 7,53 \\
S3 & 13,58 & $\mathrm{~A} 3$ & 12,40 \\
S4 & 11,11 & $\mathrm{~A} 4$ & 8,96 \\
S5 & 14,41 & $\mathrm{~A} 5$ & 9,06 \\
S6 & 10,35 & $\mathrm{~A} 6$ & 10,22 \\
S7 & 12,49 & $\mathrm{~A} 7$ & 6,35 \\
S8 & 6,94 & $\mathrm{~A} 8$ & 7,97 \\
S9 & 11,76 & $\mathrm{~A} 9$ & 9,00 \\
S10 & 6,04 & $\mathrm{~A} 10$ & 7,58 \\
S11 & 9,71 & & \\
S12 & 9,82 & & \\
S13 & 11,35 & & \\
S14 & 28,41 & & \\
S15 & 7,23 & & \\
S16 & 16,39 & & \\
S17 & 7,58 & & \\
S18 & 9,09 & & \\
S19 & 6,64 & & \\
S20 & 8,66 & & \\
S21 & 6,56 & & \\
S22 & 7,72 & & \\
\hline
\end{tabular}

Nilai kadar air pada contoh penelitian ini juga menunjukkan bahwa sebagian besar sabun yang dianalisis tidak akan mendukung terjadinya pertumbuhan mikroba. Hal ini dikarenakan nilai kadar air tersebut berada dalam nilai yang direkomendasikan aman dari mikroba yaitu 10\% - 20\% (Idoko, Emmanuel, Salau, \& Obigwa, 2018). Kadar air yang berbeda-beda tiap sabun dapat dipengaruhi oleh metode yang digunakan pada proses pembuatan sabun. Setiap produsen sabun melakukan penambahan air yang berbeda-beda tergantung formulasi sabun masing-masing produsen.

Jika dibandingkan dengan persyaratan mutu kadar air pada sabun mandi padat sesuai SNI 3532:2016, terdapat 2 sabun mandi padat yang melebihi batas mutu yang dipersyaratkan. Hal ini dapat dilihat pada Gambar 1. Dua contoh sabun mandi padat memiliki kadar air sebesar $28,41 \%$ untuk contoh S14 dan 16,39\% untuk contoh S16, sedangkan kadar air dalam persyaratan mutu yaitu maksimal $15 \%$. Dengan adanya produk sabun mandi padat di pasaran 
yang masih memiliki kadar air lebih dari 15\%, maka perlu dilakukan kaji ulang persyaratan mutu dalam SNI Sabun mandi padat. Hasil ini dapat menjadi acuan dasar untuk dilakukannya perbaikan SNI 3532:2016 pada bagian persyaratan mutu, untuk parameter kadar air, dengan usulan batas mutu kadar air diubah menjadi lebih dari 15\%. Perbaikan SNI dilakukan agar produk sabun mandi padat yang ada dipasaran dapat memenuhi persyaratan SNI sehingga dapat bersaing dengan produk-produk lainnya.

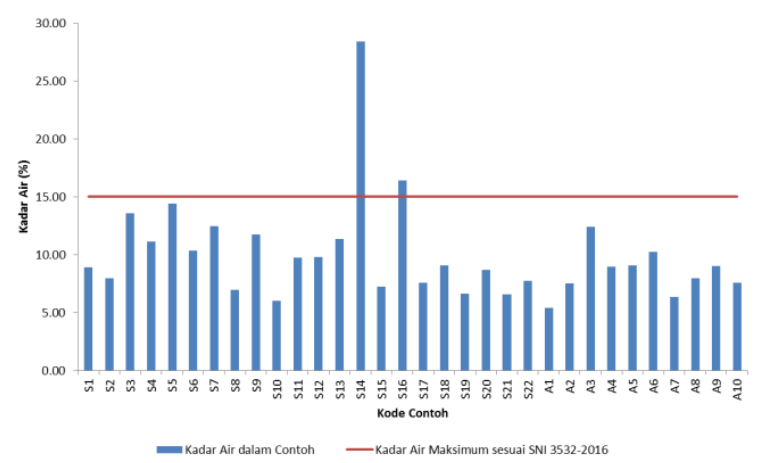

Gambar 1 Kadar air sabun mandi padat di pasaran dibandingkan dengan syarat mutu SNI 3532:2016

\section{KESIMPULAN}

Pengujian sabun mandi padat dan sabun mandi padat antiseptik yang beredar di wilayah Jakarta, Bekasi, Depok dan Bogor memperlihatkan hasil bahwa:

a. kadar $\mathrm{pH}(0,1 \%)$ berada pada kisaran 9,9910,47 dan kadar air berada pada rentang $5,42 \%-28,41 \%$;

b. dapat direkomendasikan perbaikan SNI Sabun mandi padat untuk penambahan parameter uji $\mathrm{pH}$ dengan persyaratan mutu sebesar 7 - 11 dan meningkatkan batas mutu parameter kadar air menjadi lebih dari $15 \%$;

c. dapat direkomendasikan usulan pembuatan SNI Sabun mandi padat antiseptik dengan beberapa parameter uji memiliki persyaratan mutu seperti pada SNI Sabun mandi padat.

\section{DAFTAR PUSTAKA}

American Society for Testing and Materials International. (2014). ASTM D460 - 91 Standard Test Methods for Sampling and Chemical Analysis of Soaps and Soap Products. United States: ASTM International.

American Society for Testing and Materials International. (2015). ASTM D1172-15 Standard Guide for $\mathrm{pH}$ of Aqueous
Solutions of Soaps and Detergents. United States: ASTM International. https://doi.org/10.1520/D1172-15.2

Arefin, P., Tamjid-Us-Sakib, M., Habib, S., Saha, T., \& Boby, F. Evaluation of $\mathrm{pH}$ of Facial Cleansers Available in the Bangladeshi Market.

Badan Standardisasi Nasional. (2016). Standar Nasional Indonesia Sabun mandi padat (SNI 3532). Jakarta: Badan Standardisasi Nasional.

Bureau of Indian Standards. (1997). Indian Standard Bathing Bar - Specification (IS 13498). New Delhi: Bureau of Indian Standards.

Chaudhary, N. K., Chaudhary, N., Dahal, M., Guragain, B., Rai, S., Chaudhary, R., ... Bhattarai, A. (2020). Fighting the SARS CoV-2 (COVID-19) pandemic with soap. Preprints, (May), 1-19.

Dlova, N. C., Naicker, T., \& Naidoo, P. (2017). Soaps and cleansers for atopic eczema, friends or foes? What every South African paediatrician should know about their $\mathrm{pH}$. SAJCH South African Journal of Child Health, 11(3), 146-148. https://doi.org/10.7196/SAJCH.2017.v11i3. 1325

East African Community. (2011). East African Standard Toilet soap - Specification (EAS 186) (Vol. 186). Tanzania: East African Community.

Febriani, A., Syafriana, V., Afriyando, H., \& Djuhariah, Y. S. (2020). The utilization of oil palm leaves (Elaeis guineensis Jacq.) waste as an antibacterial solid bar soap. IOP Conference Series: Earth and Environmental Science, 572(1), 1-10. https://doi.org/10.1088/17551315/572/1/012038

Habib, A., Kumar, S., Sorowar, M. S., Karmoker, J., Khatun, M. K., \& Al-Reza, S. M. (2016). Study on the physicochemical properties of some commercial soaps available in Bangladeshi market. International Journal of Advanced Research in Chemical Science, 3(6), 9-12. https://doi.org/10.20431/23490403.0306002

Idoko, O., Emmanuel, S. A., Salau, A. A., \& Obigwa, P. A. (2018). Quality assessment on some soaps sold in Nigeria. Nigerian Journal of Technology (NIJOTECH), 37(4), 1137-1140.

Mendes, B. R., Shimabukuro, D. M., Uber, M., \& Abagge, K. T. (2016). Critical assessment of the $\mathrm{pH}$ of children's soap. Jornal de Pediatria, 92(3), 290-295. https://doi.org/10.1016/j.jped.2015.08.009 
Ministry of Trade Republic of Indonesia. (2019). Export News Indonesia - Indonesia Hand Made Soap Innovation. Jakarta: Directorate General of National Export Development Ministry of Trade of The Republic of Indonesia.

Mumpuni, A. S., \& Sasongko, H. (2017). Mutu sabun transparan ekstrak etanol herba pegagan (Centella asiatica L.) setelah penambahan sukrosa. Pharmaciana, 7(1), 71-78.

https://doi.org/10.12928/pharmaciana.v7i1. 5795

Nakoe, M. R., S lalu, N. A., \& Mohamad, Y. A. (2020). Perbedaan efektivitas handsanitizer dengan cuci tangan menggunakan sabun sebagai bentuk pencegahan Covid-19. Jambura Journal of Health Sciences and Research, 2(2), 6570. https://doi.org/10.35971/jjhsr.v2i2.6563

Pakistan Standards and Quality Control Authority. (2009). Pakistan Standard for Toilet Soap (PS 13). Karachi: Pakistan Standards and Quality Contro Authority.
Takagi, Y., Kaneda, K., Miyaki, M., Matsuo, K., Kawada, H., \& Hosokawa, H. (2014). The long-term use of soap does not affect the $\mathrm{pH}$-maintenance mechanism of human skin. Skin Research and Technology, 0, 1-5. https://doi.org/10.1111/srt.12170

Tarun, J., Susan, J., Suria, J., Susan, V. J., \& Criton, S. (2014). Evaluation of $\mathrm{pH}$ of bathing soaps and shampoos for skin and hair care. Indian Journal of Dermatology, 59(5), $\quad$ 442-444. https://doi.org/10.4103/0019-5154.139861

Vivian, O. P., Nathan, O., Osano, A., Mesopirr, L., \& Omwoyo, W. N. (2014). Assessment of the physicochemical properties of selected commercial soaps manufactured and sold in Kenya. Journal of Applied Sciences, 4, 433-440.

Warra, A. A. (2013). A report on soap making in Nigeria using indigenous technology and raw materials. African Journal of Pure and Applied Chemistry, 7(4), 139-145. https://doi.org/10.5897/ajpac11.016 
